\title{
Differences in the regional stratigraphy of NE Poland caused by vertical movements due to glacioisostasy
}

\author{
WOJCIECH MORAWSKI
}

Polish Geological Institute, Rakowiecka 4, 00-975 Warsaw, Poland;

e-mail: wmor@pgi.waw.pl

\begin{abstract}
Geological mapping in combination with geophysical investigations and borehole analyses show differences of the Pleistocene between the Warmia and Mazury palaeogeographic provinces in NE Poland. The (more western) Warmia province has a crystalline basement that is covered by a folded sedimentary succession of $2-4 \mathrm{~km}$ thick. The (more eastern) Mazury province (eastern) has a basement that forms part of the rigid East European crystalline craton, which is covered by a sedimentary cover of only $1-1.5 \mathrm{~km}$ thick.

Cyclic loading by the Pleistocene ice sheets in this area induced glacioisostatic processes of different intensities, resulting in changing palaeogeographic conditions. The changes were increased by intense neotectonic activity that was induced by the ice sheets in the intermediate zone between the two provinces, stretching along the western slope of the crystalline craton. Significant part of intermediate zone forms a belt of crevasse-infill landforms deposited between the Warmia and Mazury lobes of the last glaciation. Studied deposits reveal a cyclic reactivation of the interlobe zone during the successive Pleistocene glaciations. Considerable variations of the relief of the top-Neogene, vertical discontinuities cutting the Pleistocene and Neogene, stratigraphic gaps within the Pleistocene succession, and thick glaciolacustrine successions result from the vertical neotectonic movements in the intermediate area between the two provinces.
\end{abstract}

Keywords: neotectonics, Poland, Pleistocene, stratigraphy, palaeogeography, glacioisostasy

\section{Introduction}

NE Poland is not a uniform region in terms of Pleistocene stratigraphy and palaeogeography. Both geological maps and regional field studies indicate differences between the Warmia region in the West and the Mazury region in the East. These differences were the basis for distinguishing two Pleistocene palaeogeographic provinces: the (more western) Warmia and the more eastern Mazury province (Morawski, 2005a).

The crystalline basement in NE Poland and its pre-Cenozoic sedimentary cover show also variations. The western area is characterized by both a deep-seated crystalline basement and a considerable westward-increasing thickness of the tectonically disturbed sedimentary cover of $2-4 \mathrm{~km}$ thick. The eastern area has a crystalline craton covered by a tectonically undisturbed sedimentary succession of 1-1.5 km thick (Książkiewicz et al., 1974; Tyski, 1974). The boundary between these structural units follows the western slope of the crystalline craton and the adjoining marginal trough (Kotański, 1977). This boundary, which approximately coincides with the trend of the intermediate zone between the two Pleistocene 
palaeogeographic provinces (Fig. 1), has geophysically and geologically been shown to represent a zone of neotectonic mobility that is related to Pleistocene vertical glacioisostatic movements. The vertical movements were much larger in the western area than in the east, resulting in a different palaeogeography characterizing these provinces (Morawski, 2009d-this issue).

\section{Objective}

The purpose of the present contribution is to document the geomorphological, lithological, stratigraphic and palaeoenvironmental variability within the Warmia and Mazury geologi$\mathrm{cal} /$ geomorphological provinces and the zone in between. The resulting reconstruction of the processes that operated during the Pleistocene within the intermediate zone thus will explain the factors determining differences between these two provinces.

\section{Methods}

Detailed mapping, in combination with geophysical investigations, borehole analyses and laboratory analyses, was performed in order to establish the geological structure of the study area and to reconstruct the processes that modelled the intermediate zone between the Warmia and Mazury provinces. The investigations focused on an area of approx. $600 \mathrm{~km}^{2}$ in the middle part of the intermediate zone, more precisely in the Pasym-Dźwierzuty-BiskupiecJeziorany-Kolno region (Figs. 2, 3), where the intermediate zone is best recognizable in the present-day topography.

Geological maps were prepared at a 1:50,000 scale (Morawski, 2009a,b,c). About 4500 shallow (up to $4 \mathrm{~m}$ ) and 210 deeper boreholes (up to $30 \mathrm{~m}$ ) were drilled. Data from archives regarding approx. 300 boreholes were interpreted and compared with the new-made ones. The maps of the local gravity anomaly were produced on the base of two unpublished gravimetric maps (sheet Dźwierzuty by Z. Petecki \& J. Twarogowski and sheet Biskupiec by Z.
Petecki). They were used in particular for the construction of geological cross-sections, mainly for the identification and location of discontinuity zones and the sub-Neogene surface relief. Geoelectrical sonar profiles (T. Okrasa, unpublished; B. Jagodzińska \& R. Kalitiuk, unpublished) were run over a distance of about $50 \mathrm{~km}$ (cross-sections E-F and I-J in Figs. 3 and 4). A 12-km long high-resolution reflectionseismics profile (A. Opak, unpublished) was acquired along cross-section I-J (Fig. 4).

Complete cores were obtained for analysis from six boreholes, viz. at (1) Żardeniki (153 m deep), (2) Wilimy (267 m) (Mańkowska \& Słowański, 1968, 1980), (3) Biskupiec (248 m), (4) Klucznik (303 m), (5) Nerwik (140 m) and (6) Sąpłaty (300 m). Boreholes 1,2 and 4 are located in the Warmia province, borehole 6 in the Mazury province, and boreholes 3 and 5 in the centre of the intermediate zone (Figs. 1, 3-5). All boreholes provided complete Pleistocene cores. Boreholes 2,4 and 6 represent almost the complete Cenozoic. The cores were sampled and analysed for lithology, petrography, palynology and micropalaeontology. The lithology and petrography of 31 till successions were determined in the laboratory. Data of lithological analyses (by J. Rzechowski \& B. Sobczuk, unpublished; K. Kenig, unpublished; B. Marcinkowski \& M. Wyszomierski, unpublished) were used too. The results were correlated with similar data from adjacent areas and hence their stratigraphy was established (Figs. $4,5)$.

Laboratory analyses covered also glaciofluvial, glaciolacustrine and mire deposits that separate till complexes. Sands were analysed for grain size, roundness, and morphoscopy. Till analyses included grain-size analysis, identification of heavy minerals, carbonate content, and petrography of 5-10 $\mathrm{mm}$ gravel.

The stratigraphy was established on the basis of both regional correlations and the till lithostratigraphy as characterized by petrographic coefficients, which are based on the ratio of Scandinavian to Baltic rocks: O/K, K/W and $\mathrm{A} / \mathrm{B}$ (in which $\mathrm{O}=$ sedimentary rocks; $\mathrm{K}$ = crystalline rocks and quartz; $\mathrm{W}=$ carbonate rocks; $\mathrm{A}=$ rocks non-resistant to weathering; $\mathrm{B}$ $=$ resistant to weathering). The values of pet- 

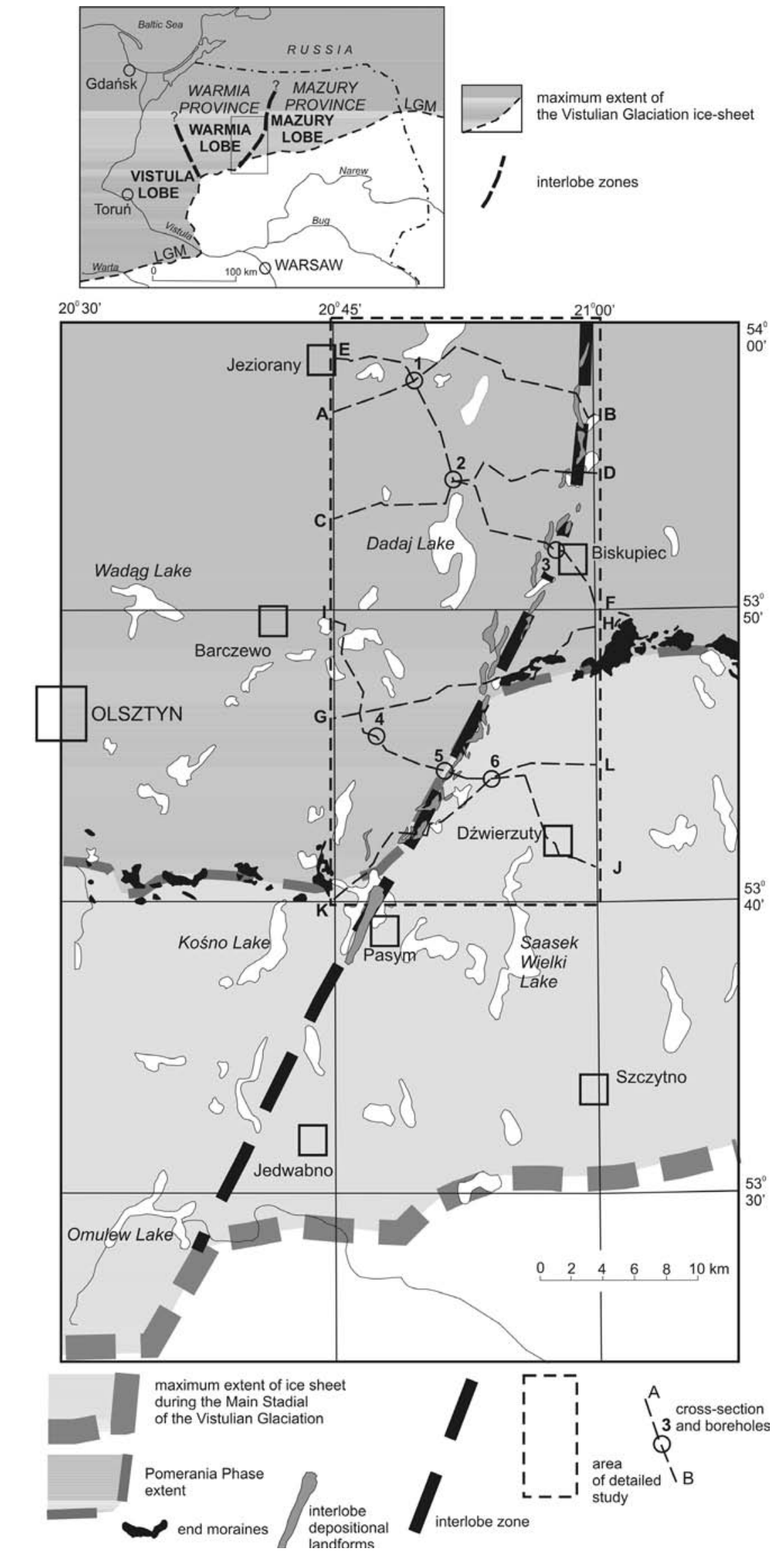

Fig. 1. Location of intermediate (interlobe) zone and positions of ice-sheet margin during the Vistulian Glaciation. 
rographic coefficients have been published in Kenig (1998) and Lisicki (2003).

Palynological and macrofaunal investigations were carried out on the Neogene and Palaeogene deposits for boreholes 4 and 6, allowing to establish a detailed stratigraphic subdivision (Słodkowska, 2009-this issue).

The local and regional ice-movement directions during the last glaciation within both ice lobes was reconstructed by analysis of linear glacial landforms (morpholineaments) (Morawski, 2003c, 2005b, 2009d-this issue).

\section{Geographical and geological setting}

The study area is situated in the western part of the Mazury Lakeland, NE Poland. Its western part belongs to the Olsztyn Lakeland, and the eastern flank is located within the Mrągowo Lakeland.

\section{The Warmia province}

The Warmia province is characterised by discontinuous till horizons at various altitudes. The tills have commonly been eroded away completely, so that only residual boulder layers are left. Early Pleistocene till complexes of considerable thickness occur at a local scale only in deep erosional scours and depressions formed by glacial erosion. The only area where till form continuous, locally thick horizons is the northern part of the province. In a single borehole, even 8-9 till horizons can occur superimposition: two till horizons of the Nidanian glaciation (Cromerian complex - glacial A), the Sanian 1 (Elsterian 1) and Sanian 2 (Elsterian 2), the Odranian (Drenthian), and two till horizons from both the Wartanian (Warthian) and the Vistulian (Weichselian).

In the South of the province, the Pleistocene is dominated by glaciofluvial and glaciolacustrine deposits that commonly form thick complexes. Glaciofluvial successions fill channels that are often deeply incised into each other. Thick glaciolacustrine successions are com- monly of local extent. Another common feature are sedimentary hiatuses that may span even few glaciations. Interglacial deposits are almost absent. These features prove intensive activity of cyclic erosional processes.

\section{The Mazury province}

The Pleistocene of the Mazury province commonly shows a considerable thickness (locally more than $250 \mathrm{~m}$ ) and laterally continuous lithostratigraphic units containing many tills interbedded between organic interglacial deposits. Organic successions allowed palynological dating of the interglacials and interstadials The entire succession comprises 15 till units. They were assigned to individual glaciations and stadials based on regional correlations and laboratory analyses of their petrography and lithology (Lisicki, 2003). The till horizons are attributed to the following glaciations: two stadials of Narewian (Menapian); two stadials of Nidanian (Cromerian Complex - Glacial A); two stadials of Sanian 1 (Elsterian 1); two stadials of Sanian 2 (Elsterian 2); Liwiecian (Fuchne); two stadials of Odranian (Drenthian); two stadials of Wartanian (Warthian); and two stadials of Vistulian (Weichselian).

\section{The intermediate zone}

Geomorphological and geological investigations show that the Warmia and Mazury provinces coincide with the extent of two ice lobes of the last (Vistulian) glaciation ice sheet, the Warmia and the Mazury lobes (Fig. 1). The interlobe zone coincides with the intermediate zone between the two provinces. Structural studies suggest that tectonic mobility of the intermediate zone, induced by glacioisostatic movements, resulted in the formation of interlobe zones of similar location during the successive Pleistocene glaciations (Morawski, 2009d-this issue).

In the topography and near-surface geological structure, the intermediate zone is manifested in the form of a narrow, NNE-SSW trending belt of crevasse-fill landforms composed of sand/gravel deposits. It stretches 


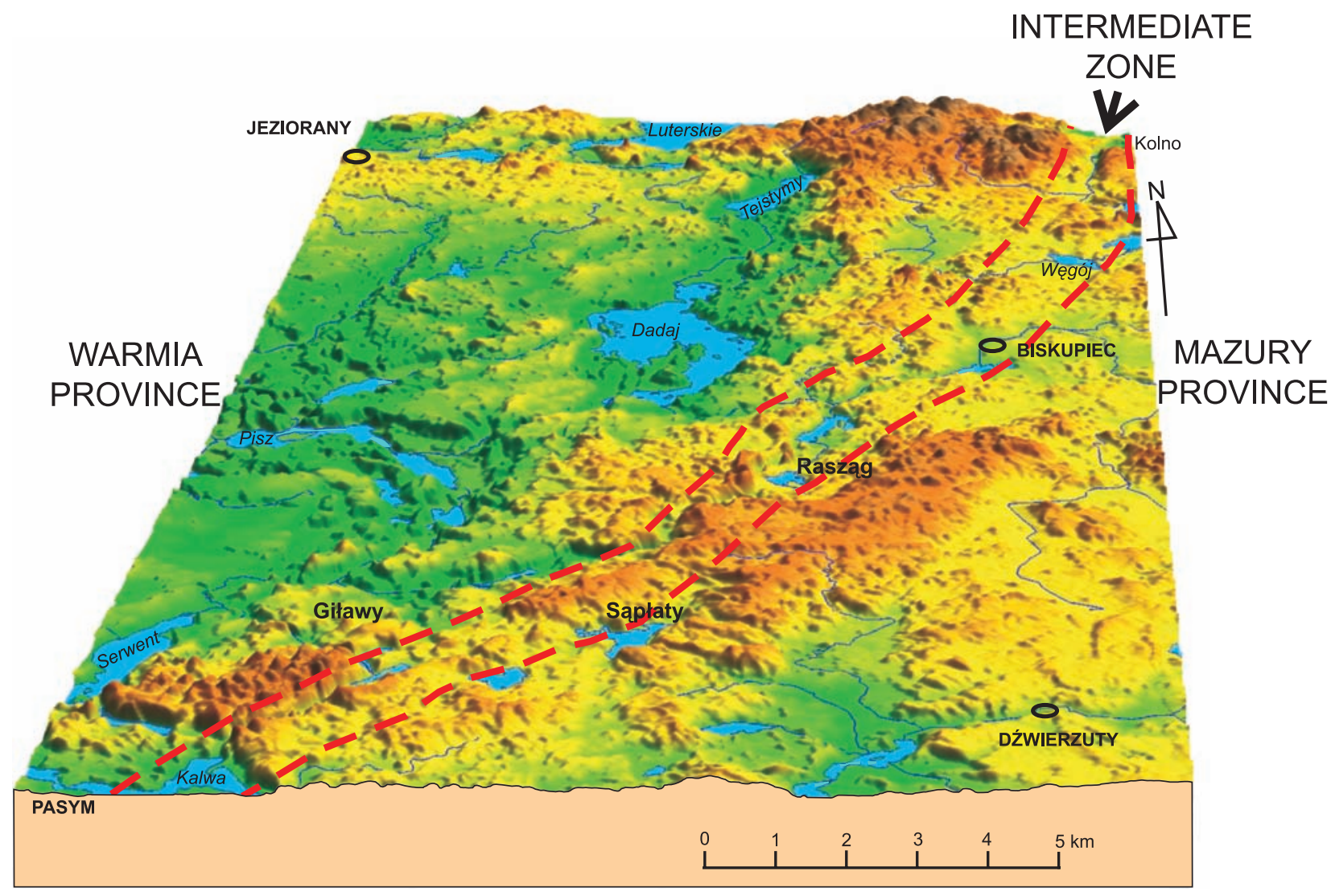

Fig. 2. Digital model of the studied area.

over approx. $80 \mathrm{~km}$ from the Omulew Lake in the South trough Pasym and Biskupiec and further towards the NE to Reszel in the North (Fig. 1). Its width varies from a few hundred metres to some kilometres. The zone is best expressed in the middle sector of the study area (Pasym-Biskupiec-Kolno) (Figs. 2, 3).

\section{Geomorphology}

The present-day topography of the area came into existence during the retreat of the ice sheet of the last stadial of the Vistulian glaciation from the area between the Mazury and Warmia lobes.

\section{The Warmia province}

The western part of the study area developed as a result of deglaciation of the Warmia lobe and now forms the Olsztyn Upland. This region is topographically diverse; the differ- ence in elevation between the lowest and highest points is nearly $150 \mathrm{~m}$. Numerous kame hills, extensive kame plateaus, kame terraces and glaciolacustrine plains exist there.

The area is cut by deep, NNE-SSW trending subglacial tunnel valleys that are often filled with lakes. The valleys are commonly narrow and very deeply incised (up to $100 \mathrm{~m}$ ). The maximum lake depth is about $40 \mathrm{~m}$. Broad, flat-bottomed valleys are also present. In the northern part of the area abundant dead-ice moraines occur. The drainage network of the area, with numerous kettle holes, is poorly developed.

Analysis of the orientation of linear glacial landforms (glacial morpholineaments) indicates differences in their arrangement. In the North, four major sets of directions are present (Fig. 6). The dominant N-S direction is connected with the subordinate W-E direction. The remaining linear landforms show less well developed preferred orientations, but two sets, running perpendicular to each other in NNWSSE and NNE-SSW directions can be distin- 
guished. In the central part of this western area, most of the linear landforms are oriented NW-SE and NNW-SSE, together with subordinate direction NE-SW (Fig. 6). In the South, the morpholineament orientations are poorly developed, but it is possible to identify four sets forming two conjugate systems oriented like those in the northern part (Fig. 6).

\section{The Mazury province}

The topography of the eastern part of the study area was shaped during deglaciation of the Mazury ice lobe. The hummocky Szczytno Upland (Figs. 2, 3) was then formed. It is composed of tills with small landforms of dead-ice moraines and kettle holes. The upland lies at a higher altitude than the western area of the Olsztyn Upland. The relief shows height differences of several metres only. The drainage network is poorly developed. The easternmost periphery of the area is occupied by an outwash plain extending towards the East. In the central part, in the Rasząg-Botowo-Labuszewo region (Fig. 2), the belt of endmoraines marks the extent of the Pomeranian Phase of Weichselian (Fig. 1).

The orientation of linear landforms, in the south-eastern part of this area shows a predominant NW-SE direction (Fig. 6). To the east, the dominant NNW-SSE direction is typical of the Mazury lobe of last glaciation (Morawski, 2005b).

\section{The intermediate zone}

Between the areas described above, a hummocky belt, being a glaciofluvial upland is present. It is covered with landforms built by the infilling of crevasses and subglacial channels. This NNE-SSW trending belt is identified with an interlobe zone (Figs. 2, 3).

The landforms constituted by crevasse infillings occur as linear ramparts stretching in NNE-SSW direction. They are a few hundred metres to about $2 \mathrm{~km}$ long and several tens to a few hundreds of metres wide. Their relative height is from several to 20 metres. North of
Biskupiec, the zone changes its direction (to N-S) and geomorphologic character too. Slightly undulating belt of the glaciofluvial upland is dominated by elongated depressions and small isometric dead-ice moraines. The ridges consisting of sediments deposited in ice-sheet crevasses are present further northwards. An important element determining the relief of the zone is the presence of narrow valleys deeper than $60 \mathrm{~m}$.

\section{Lithology, stratigraphy and palaeogeography}

\section{The Pre-Pleistocene}

In the Warmia province, the Early Palaeozoic deposits were folded during the Caledonian orogeny before the Arenigian (Middle Ordovician). The Lower Palaeozoic is unconformably overlain by the Arenigian, which is, in turn, covered by Late Palaeozoic and Mesozoic formations. The eastern periphery of the area coincides with the crystalline craton slope and the Napiwoda-Purda-Ryn-Garbowo marginal trough. The trough is pre-Arenigian tectonic palaeostructure (Kotański, 1977). In the Mazury province, the western end of the East European craton forms the hypothetical Giżycko-Szczytno-Różan elevation. The sedimentary cover is poorly developed here; the Palaeozoic is absent, but the Mesozoic deposits form a continuous, undeformed succession.

Complete Neogene and almost complete Palaeogene successions were encountered in boreholes on both sides of the intermediate zone. The thicknesses of the corresponding lithostratigraphic units are comparable both of the Warmia and the Mazury province, and the sedimentary conditions during the Neogene and Palaeogene were identical (Słodkowska, 2009-this issue).

The top-Neogene surface relief is illustrated in six cross-sections through the marginal parts of the Mazury and Warmia provinces (Fig. 4). On the eastern (Mazurian) side, the top-Neogene surface is relatively flat; it lies 

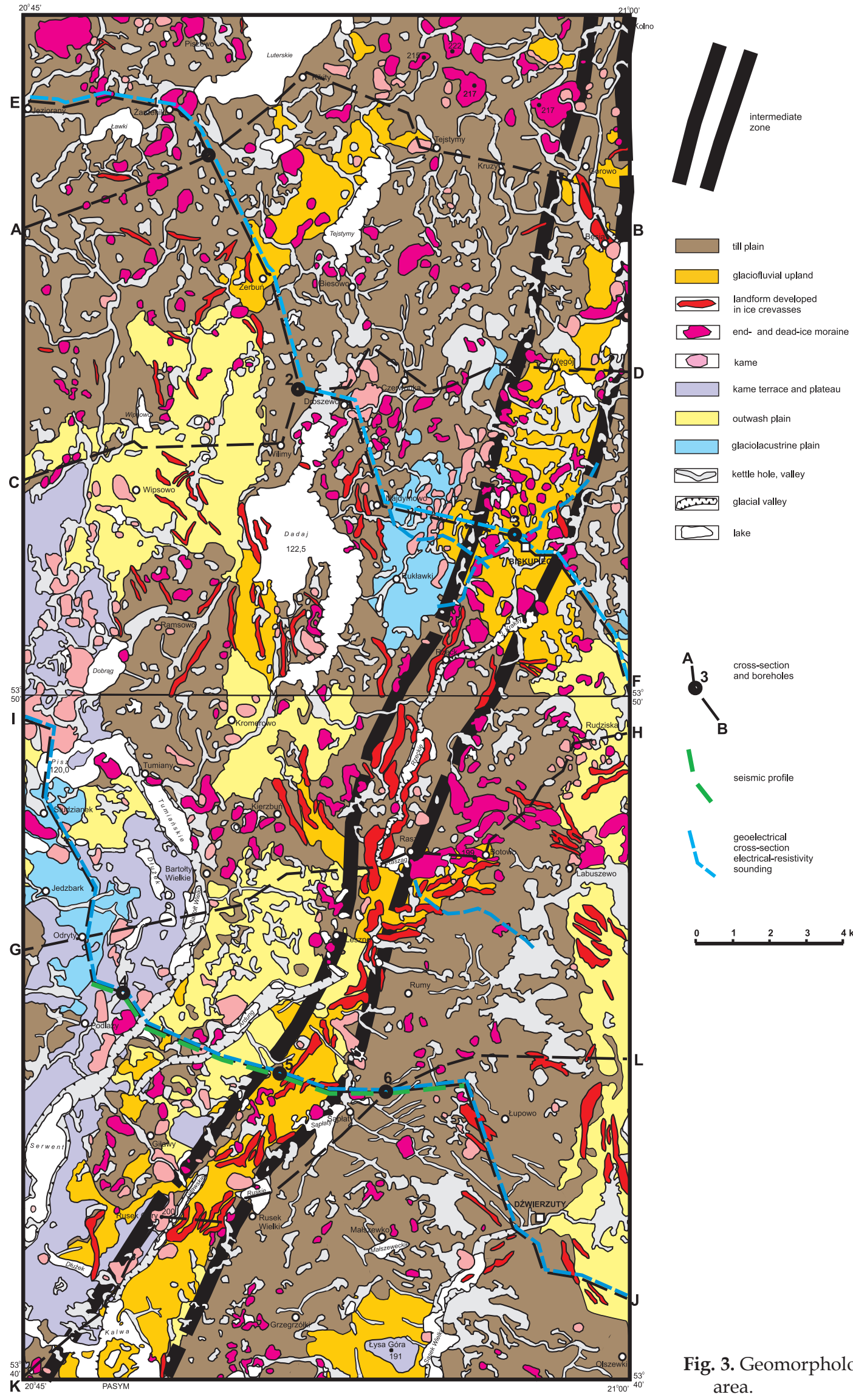

$1 \begin{aligned} & \text { geoelectrical } \\ & \text { cross-section } \\ & \text { electrical-resistivity } \\ & \text { sounding }\end{aligned}$

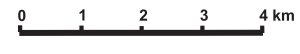

Fig. 3. Geomorphology of the studied area. 
at an altitude of approx. 40-60 m a.s.l. On the western (Warmian) side, it is situated at about 0-20 m a.s.l. Seismic data (see Fig. 3 in Morawski, 2009d-this issue) and the lithology in boreholes indicate that several vertical discontinuities exist within the intermediate zone. They can be considered as fault zones running approximately from NNE to SSW. The depth of the top-Neogene changes in this area, ranging from about $90 \mathrm{~m}$ a.s.l. to $90 \mathrm{~m}$ b.s.l. (Fig. 4).

The pre-Pleistocene basement is composed of Mio-Pliocene and Miocene deposits; clay interbedded with silt and fine-grained sand, occasionally with thin lignite layers.

\section{The Pre-Vistulian Pleistocene}

The lithological and stratigraphical terminology of the Pleistocene units, used in the present contribution follows that applied for NE Poland, complemented by equivalents from western Europe, mainly Germany (Ber, 2006).

The thickness of the Pleistocene deposits on the Warmian side (Fig. 5) varies from 113 to 165 $\mathrm{m}$. Geophysical investigations indicate, however, that the maximum thickness can reach $200 \mathrm{~m}$. On the Mazurian side, the thickness of the Pleistocene deposits is $80-140 \mathrm{~m}$ (Fig. 4). In the intermediate zone, the thickness of the Pleistocene (Fig. 5) changes from 135 to $243 \mathrm{~m}$. The thickness can be locally reduced by glaciotectonic deformation or/and vertical movements of tectonic blocks, with relative changes in height up to approx. $40 \mathrm{~m}$ (cross-section I-J in Fig. 4).

\section{The Narewian glaciation (Menapian)}

Two Narewian tills corresponding to two stadials occur in the Mazury province (Lisicki, 2003). In the Warmia province, tills that may represent this oldest glaciation occur sporadically only in the northern part. Glaciofluvial deposits directly overlie the Neogene over an extensive area. These deposits were probably accumulated during retreat of the Narewian ice sheet.

Only one Narewian till, a few metres thick, is present in the intermediate zone (Figs. 4, 5). The till contains detached fragments of Neogene clays, thin concretions of ferruginous clay, fragments of wood and local rocks, and occasional Scandinavian crystalline erratics. The composition of the heavy minerals suggests that the till consists mainly of reworked Neogene deposits.

The overlying sands, which are 5-15 m thick, are separated from the till by a boulder layer. The sands derived from redeposition of Neogene substratum together with the oldest Pleistocene deposits. The good rounding, very good sorting and the assemblage of the heavy minerals indicate long fluvial transport. The deposits represent a reach of N-S trending river valley, coinciding with the direction of the intermediate zone. This might be due to downward movements in this zone. The differences in elevation of the Narewian till on both sides of the intermediate zone (cross-section I-J in Fig. 4; Fig. 5) are worth mentioning in this context. In the Warmia province, the till is situated about $30 \mathrm{~m}$ lower than in the Mazury province.

\section{The Nidanian glaciation (Cromerian Complex - Glacial A)}

Three successive Nidanian deposits occur to the East of the intermediate zone: glaciolacustrine deposits deposited during ice-sheet advance, a till complex and glaciofluvial sediments deposited in front of the retreating ice margin (see borehole 6 and cross-section I-J in Fig. 4). On the western side, a complex with two tills is situated approx. $50 \mathrm{~m}$ lower than the till at the eastern side.

No tills have been preserved in the central southern part of the intermediate zone (borehole 5 in Figs. 4 and 5). In the northern part of the intermediate zone (borehole 3 and crosssection E-F in Fig. 4), two thin till units interca- 


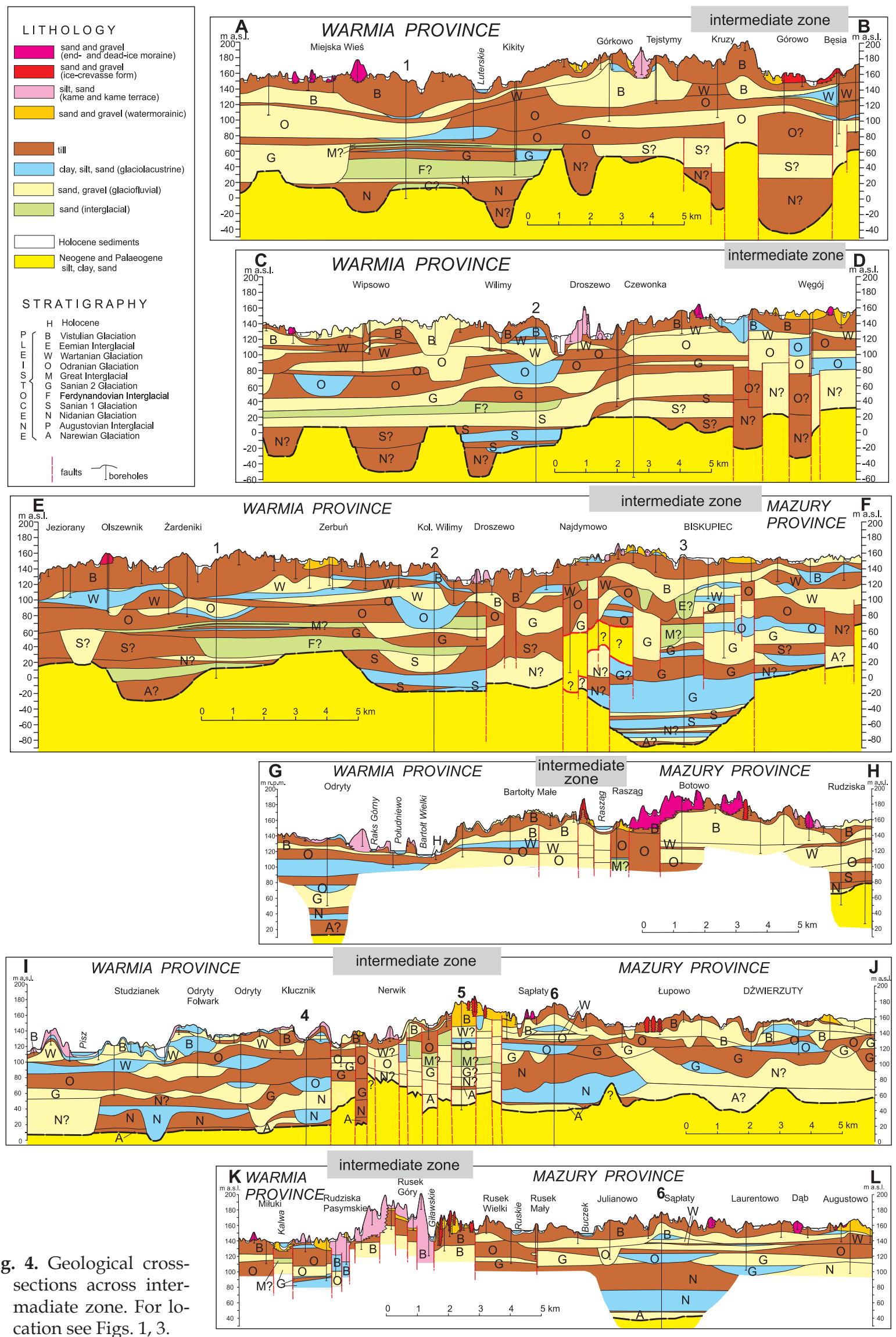


lated with sand occur; they are more than 150 $\mathrm{m}$ lower in altitude than in the eastern area.

\section{The Sanian 1 glaciation (Elsterian 1)}

In the Mazury region, the Sanian 1 till (Kasprzak \& Lisicki, 1999) is several metres thick; its position is at an altitude of approx. $80 \mathrm{~m}$ a.s.l. (see cross-section G-H in Fig. 4). In the Warmia province, the till is over $30 \mathrm{~m}$ thick and occurs at an altitude of about $25 \mathrm{~m}$ a.s.l., (Morawski, 2001, 2003a) i.e. approx. $55 \mathrm{~m}$ lower than in the Mazury region (see cross-section E-F in Fig. 4). Also on the western side, but closer to the intermediate zone (cross-sections C-D and E-F in Fig. 4; borehole 2 in Fig. 5), the two till horizons occur at an altitude of about $17 \mathrm{~m}$ b.s.l., i.e. almost $100 \mathrm{~m}$ lower than in the East.

\section{The Sanian 2 glaciation (Elsterian 2)}

The Sanian 2 sedimentary succession starts from thick clay and mud series (borehole 3 in Fig. 5), which was deposited in an ice-dammed lake, probably during ice advance. The lake had formed in a deep depression extending along the axis of the intermediate zone, indicating local strong subsidence (Morawski, 2009d-this issue). Two horizons of Sanian 2 till occur in the Warmia province. They are overlain by glaciofluvial deposits representing the recessional stage (boreholes 1 and 2 in Fig. 5; see crosssection E-F in Fig. 4). On the Mazurian side, a similar succession occurs at a 40-50 m higher altitude, interpreted from geophysical investigations. In the central part of the intermediate zone (borehole 3 in Fig. 5; see cross-section E-F in Fig. 4), the base of the Sanian 2 till lies almost $50 \mathrm{~m}$ lower than on the Warmian side and some $100 \mathrm{~m}$ lower than in the Mazurian side. Glaciofluvial sands and gravels deposited during ice-sheet retreat in the eastern region are situated $50 \mathrm{~m}$ higher than in the western region.

\section{The Great Interglacial (Holsteinian) (?)}

Deposits which age is interpreted as the Great Interglacial have been encountered in the central part of the intermediate zone (borehole 5 in Fig. 5). They are represented by a succession of fine- and medium-grained sand with intercalations of mud and containing dispersed organic matter. Winter (2005) mentioned a predominance of coniferous tree pollen and a small amount of deciduous trees. The palynological spectrum reflects a pine forest with spruce, larch, birch and alder of wetland areas. The sedimentation took place during the warm period. Similar sand and mud series with plant detritus occurs in the central part of the intermediate zone (borehole 3 in Fig. 5). The upper part of succession contains the boulder layers which suggest fluvial accumulation followed by erosional phases. Mentioned succession presumably represent alluvial deposits of a valley stretching in the intermediate zone.

\section{The Odranian glaciation (Drenthian)}

The Odranian deposits form two till horizons and probably represent two stadials. The lower till is underlain by clays, muds and sands deposited in small ice-dammed lakes that developed during ice-sheet advance. They occur mainly in the central and southern parts of the study area. In the southern part of the Warmia province (borehole 4 in Figs. 4, 5), thick Odranian succession (including a till complex of $46 \mathrm{~m}$ ) occurs. Such a thick till complex was also found in the other boreholes located on Mazurian side of the intermediate zone (see cross-section G-H in Fig. 4). In the Mazury province, the Odranian till complex occurs almost $50 \mathrm{~m}$ higher than in the Warmia region (borehole 6 in Figs. 4, 5). 


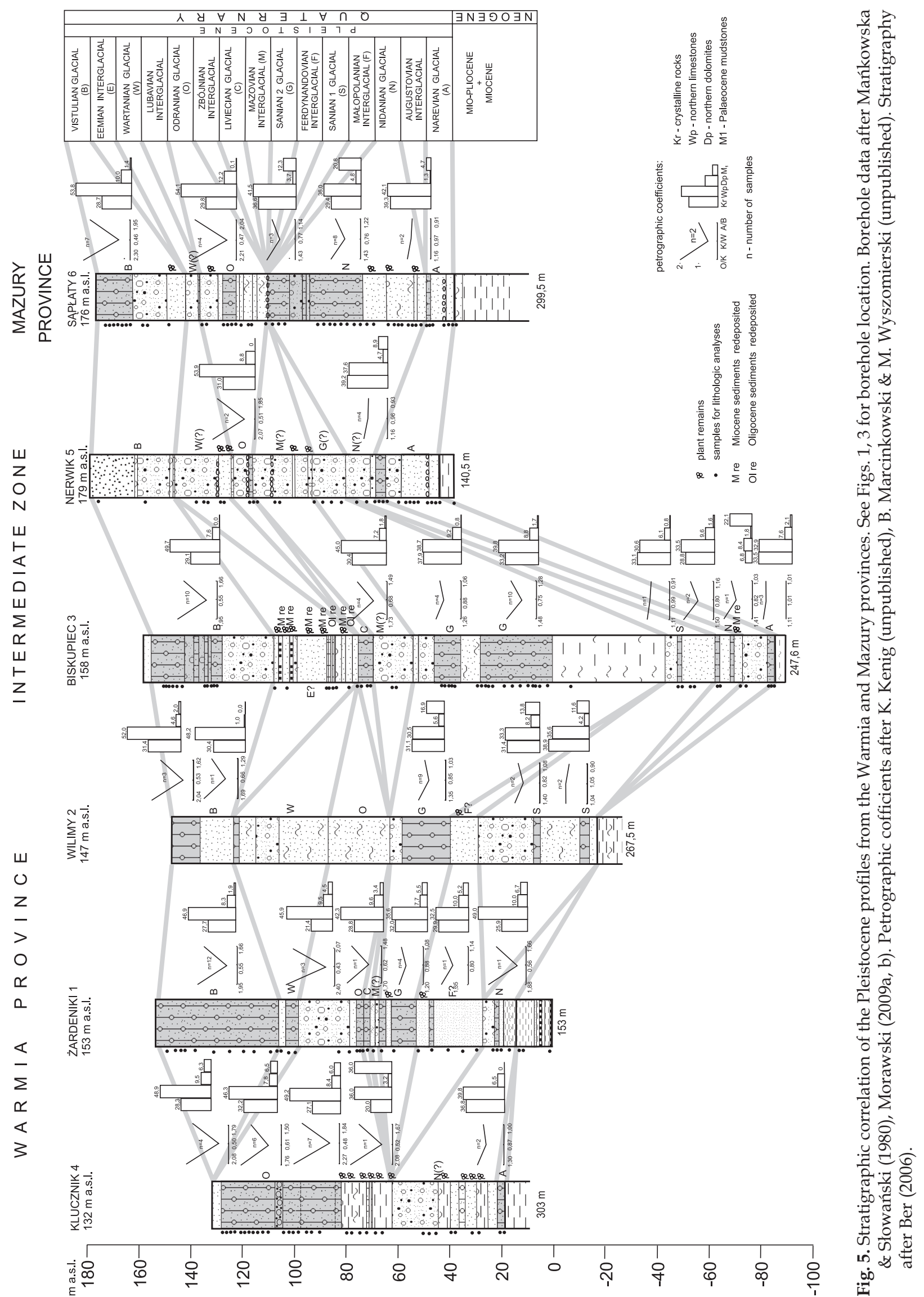




\section{The Wartanian glaciation (Warthian)}

In the southern part of the study area, Wartanian deposits are absent or preserved only fragmentarily. In the North, a Wartanian till occurs as a thin layer in both the Warmia and the Mazury provinces. Locally, the till forms a complex of two horizons. In the intermediate zone, there is usually only a horizon of clayey pavement. A number of laterally discontinuous successions of ice-dammed lake deposits were accumulated during ice advance, whereas glaciofluvial deposits are interpreted as sedimentary record of ice retreat.

\section{The Eemian(?) interglacial}

The Eemian interglacial is represented by lacustrine deposits containing some Miocene and Oligocene redeposited material. They occur in the central part of the intermediate zone (borehole 3 in Fig. 5; cross-section E-F in Fig. 4). Poorly preserved Pleistocene and Neogene pollen specimens occur. Lacustrine deposits indicates local subsidence of this part of the intermediate zone. Redeposition of Miocene and Oligocene deposits suggests the presence of locally uplifted parts of the intermediate zone. One of such Neogene blocks was drilled at 60-70 m a.s.l. at Najdymowo, west of Biskupiec (see cross-section E-F in Fig. 4).

\section{Vistulian glaciation (Weichselian)}

Four units compose the Vistulian sedimentary succession: two lower ones deposited during ice-sheet advance (glaciolacustrine and glaciofluvial units), the main unit of glacial till and the upper unit of glaciofluvial and glaciolacustrine deposits formed during ice retreat.

The glaciofluvial sands and gravels deposited during ice-sheet advance occur as a laterally continuous, few to more than $20 \mathrm{~m}$ thick unit, both in the southern part of the Mazury province (cross-sections G-H, I-J and K-L in Fig. 4) and in the northern part of the Warmia prov- ince (cross-section A-B in Fig. 4). Locally, the thickness of this unit increases to over $50 \mathrm{~m}$.

Till is the marker glacial unit in this area; it covers the glacial upland of the southern part of Mazury province. In the central and northern parts of the study area, it occurs on both sides of the intermediate zone. The till forms a laterally continuous horizon of several metres thick (locally up to $50 \mathrm{~m}$ ).

The glaciofluvial and glaciolacustrine units that were formed during ice retreat, dominate in the Warmia region. They built the landforms such as outwash plains, kame terraces, kame plateaus and ice-dammed lake plains.

The intermediate zone is a belt of glaciofluvial upland, which represents an area built by sediments that were deposited in interlobe area. Deposition took place at the contact with dead-ice masses. In this way derived the sands and gravels, commonly very poorly sorted, often with large boulders and intercalations of muds. They contain lenses of diamictic debrisflow deposits occasionally. Such deglaciationderived facies, deposited close to dead-ice, was defined by Morawski $(1984,1985,1989)$ as 'watermorainic deposits'. In the central part of the interlobe zone, the series can be over $35 \mathrm{~m}$ thick, as in borehole 5 (cross-section I-J, Fig. 4).

The Mazury province forms a hummocky glacial upland. The morphology of Warmia province is more complicated due to complex deglaciation. In the southern part of this region, high kame hills, kame plateaus, kame terraces and local ice-dammed lake plains developed. Moreover, deep glacial channels were partly filled with lakes. The northern part is a tillplain and local outwashes (Fig. 2).

\section{Discussion and conclusions}

The study area lies within a zone occupied by the last Scandinavian ice sheet. Northeastern Poland was covered by ice stream, which moved from the NNW towards the SSE (Punkari, 1997; Boulton et al., 2001; Stokes \& Clark, 2001; Houmark-Nielsen \& Kjoer, 2003), referred to in the Polish literature as the 'Mazury ice lobe'. To the West, another ice stream occurred, called the 'Vistula ice lobe' (Roman, 


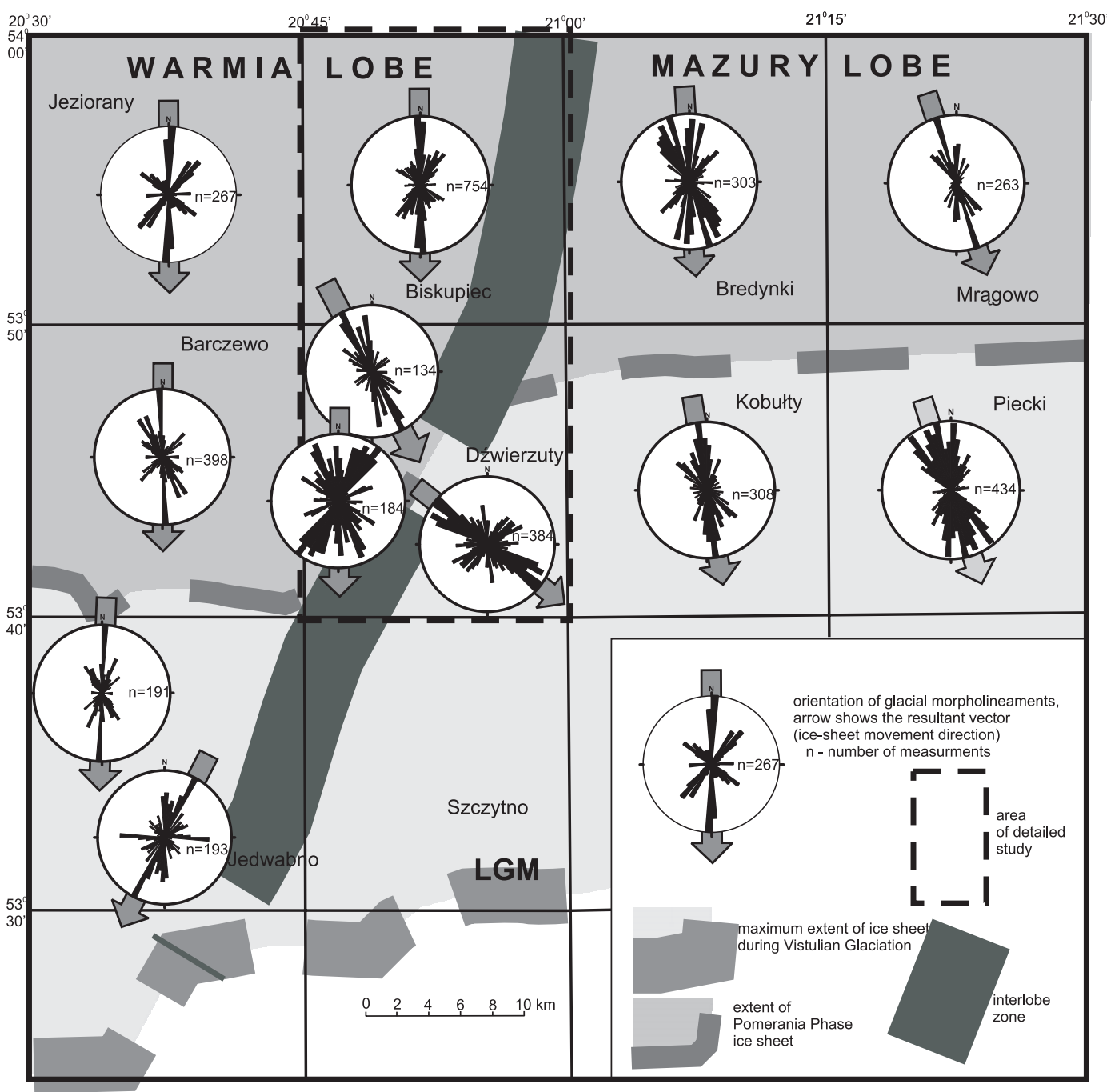

Fig. 6. Directions of ice-sheet advance on E Warmia and W Mazury areas. LGM - last glacial ice-sheet margin.

2008; Wysota et al., 2009). The reconstruction of ice-movement directions, through analysis of the orientation of linear glacial landforms (Morawski, 2003c, 2005b), shows that the dominant direction in the Mazury region is from NNW to SSE (Fig. 6).

Geomorphological analysis revealed a linear zone of several kilometres wide with NNESSW trending ridges derived from ice-crevasse infilling. The zone is expressed in the topography along a distance of some $60 \mathrm{~km}$. The maximum ice-sheet extent of the Mazury lobe runs approx. $20 \mathrm{~km}$ south of the study area. In the West the maximum ice-sheet margin was extended about $8 \mathrm{~km}$ more towards the South (Figs. 1 and 6).

To the west of mentioned zone, the ice moved mainly N-S, typical of the Warmia area.
In the immediate neighbourhood of the intermediate zone, the directions show local variability (Fig. 6).

It can thus be hypothesized that an interlobe zone was formed when the Warmia lobe became isolated from the Mazury lobe. Initially, the Warmia lobe was triangle in shape and joined the Vistula ice lobe in the West (Fig. 1). The process of isolation of the Warmia lobe was accompanied by a change in the ice-movement direction more to the South, and probably by acceleration of the movement, resulting in a farther southward extent than the Mazury lobe (Fig. 7). An extensive glacial upland developed in the Mazury area. It is composed of tills with an outwash plain in the eastern part. In the Warmia area, kames, ice-dammed lake plains, glacial channels developed. They de- 

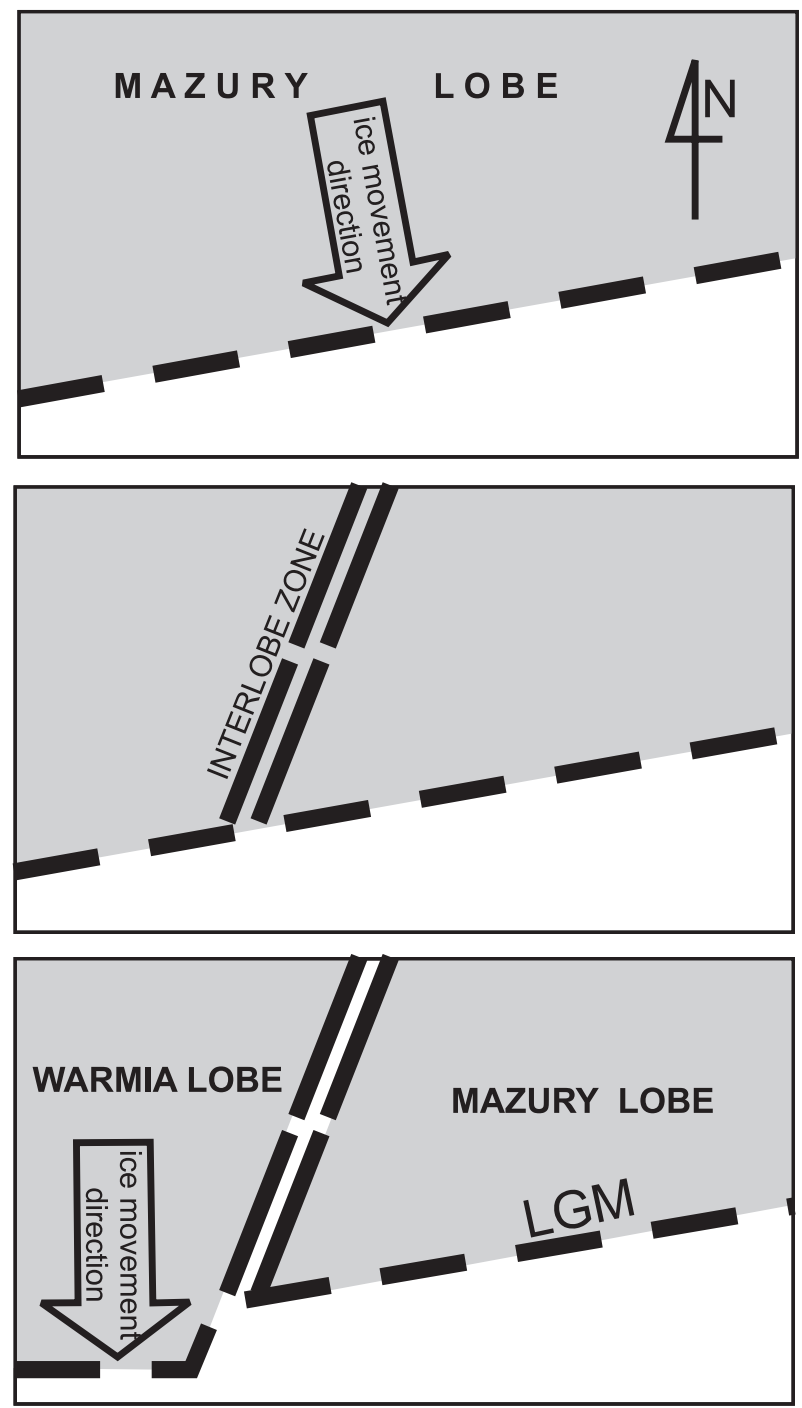

Fig. 7. Development of interlobe zone. LGM - last glacial ice-sheet margin.

rived in local depressions and tensional crevasses which were formed on/in the ice sheet.

The linear, NNE-SSW trending zone of landforms built by sediments accumulated in ice-sheet crevasses is well expressed in the topography. This was an interlobe zone, along which the Mazury lobe became divided from the Warmia lobe, and which moved some $8 \mathrm{~km}$ farther southwards than the Mazury lobe during the Main Stadial of Vistulian.

After interlobe zone formation the ice-sheet direction of Warmia lobe was changed from NNW-SSE to N-S (Fig. 7).

The formation of two lobes together with interlobe zone probably was a result of strong glacioisostatic subsidence of the Warmia re- gion (cf Morawski, 2009d-this issue). The subsidence resulted in a downward movement of the ice-sheet substratum towards the west along the intermediate zone, causing acceleration of the ice flow in the western area, i.e. the Warmia lobe (see ice-sheet extent in Fig. 1).

Downward movements of the substratum towards the west during the deglaciation resulted in both a subdivision of the Warmia lobe into individual ice blocks and deposition in crevasses and ice-dammed lakes.

In the central part of the study area, a zone in which the ice-sheet margin stagnated (Pomeranian Phase of Vistulian) is expressed by a well-developed belt of frontal moraines (Figs. 1 and 3). In the West, in the Warmia area, frontal-moraine belt lies in more southward position than in the East (the Mazury area) (Fig. 1).

When the activity of the Vistulian ice sheet increased during the Pomeranian Phase, the Warmia lobe advanced again approx. $15 \mathrm{~km}$ farther southwards along the interlobe zone than the Mazury lobe.

Two Pleistocene palaeogeographic provinces (Warmia and Mazury) can be distinguished. They are divided by intermediate zone. The Mazury (eastern) province is characterised by a continuous succession of Pleistocene deposits, in particular tills that mark several phases of advance of the Scandinavian ice sheet. These Pleistocene marker horizons exist on the constant altitudes. In the Warmia (western) province considerable stratigraphic gaps occur. The tills occur as lenses and do not form continuous horizons. They are separated by thick glaciofluvial and glaciolacustrine deposits.

The Pleistocene successions in the Warmia and Mazury provinces represent different arrangement of Pleistocene sedimentary succession, indicating different palaeogeographical processes during deglaciation of Warmia and Mazury ice-sheet lobes. NNS-SSW trending boundary between the provinces coincides with the interlobe zone.

The question arises of what were the reasons for the palaeogeographical differences between the two provinces and for the formation and location of the intermediate zone. Other questions are about the relationship of the boundaries between these zones and the 
interlobe zone that developed during the last glaciation, and about the cause of the change in the direction of the iceflow and of the acceleration on the western Warmian side.

The Pleistocene successions of the Warmia province occur at much lower altitudes than their equivalents on the eastern Mazury area. Significant lateral variations within the whole Pleistocene architecture occur in the intermediate zone. They suggest vertical neotectonic mobility of the substratum and hence local differentiation of sedimentary and erosional conditions. The Pleistocene successions are locally reduced in thickness and are composed almost exclusively of unsorted and very poorly washed sands, gravels and boulders. Considerable stratigraphic gaps suggest strong erosional processes that occurred throughout the Pleistocene. The Neogene substratum is locally situated several tens of metres higher than in the adjoining areas (see cross-section I-J in Fig. 4). These facts seem to indicate that vertical upward movements dominated in the southern part of the intermediate zone. In the northern region, the top-Neogene is situated in some areas about $100 \mathrm{~m}$ lower than the average for the adjoining areas. The Pleistocene succession includes there thick glaciolacustrine and lacustrine series that are absent in other areas (cross-section E-F in Fig. 4). The upper deposits contain reworked Miocene and Oligocene material, indicating strong erosion of the substratum that occurs nearby at high altitudes. Subsidence thus dominated in the north of the intermediate zone, although there was locally a simultaneous strong uplift of the substratum.

Geophysical investigations and borehole data prove the occurrence of numerous vertical discontinuities in the intermediate zone (Morawski, 2009d-this issue). They most likely follow the orientation of intermediate zone axis. Vertical (stepwise) tectonic movements of blocks occurred along the discontinuities. Strike-slip movements cannot be precluded, either. Tectonically active intermediate zone probably existed in the same position throughout the whole Pleistocene; it was repeatedly reactivated during successive glaciations. Vertical movements of blocks occurred within the intermediate zone. They were induced probably by cyclic glacioisostasy.

Detailed investigations of the palynology and microfauna of the Neogene and Palaeogene succession, performed on both sides of the intermediate zone (boreholes 4 and 6 in cross-section I-J Fig. 4), prove the similarity of both sedimentary conditions and thickness of the individual stratigraphic units (Słodkowska, 2009-this issue). Palaeogeographical differences between the Warmia and Mazury provinces refer only to the Pleistocene, which makes it likely that this results from a different response of the basement in the two areas to the advances and retreats of the successive ice sheets.

Cyclic loading by the Pleistocene ice sheets caused vertical glacioisostatic movements of the basement. The Warmia area underwent relatively much subsidence. Cyclic loading by the ice sheets resulted in unequal compaction of the sedimentary succession. The compaction was stronger on the western side due to the thicker sedimentary cover. As a result, the individual Pleistocene successions on the western side are situated at lower altitudes.

Ice-sheet retreat caused relatively much vertical glacioisostatic uplift on the western side. This gave rise to intense erosion and resulting stratigraphic gaps in the Warmia province.

The intermediate zone was subjected to significant vertical movements, indicating strong neotectonic activity at the boundaries of structural units in the basement. The movements were induced by cyclic advances and retreats of the Pleistocene ice sheets.

\section{References}

Ber, A., 2000. Pleistocene of north-eastern Poland and neighbouring areas against crystalline and sedimentary basement. Prace Państwowego Instytutu Geologicznego 170, 89 pp.

Ber, A., 2006. Peistocene interglacials and glaciations of northeastern Poland compared to neighbouring areas. Quaternary International, 149, 12-23.

Boulton, G.S., Dolgenmans, P., Punkari, M., Broadgate, M., 2001. Palaeoglaciology of an ice sheet through a glacial cycle: the European ice sheet through the Weichselian. Quaternary Science Revievs 20, 591-625.

Gagel, C., Müller, G., 1897. Die Entwickelung der Ostpreussischen Endmoränen in den Kreisen Ortelsburg 
und Neidenburg. Separatabdruck aus dem Jahrdbuch der Königl. Preuss. Geologischen Landesanstalt für 1897. Berlin.

Houmark-Nielsen, M., Kjoer, K.H., 2003. Southwest Scandinavia, 40-15 kyr BP: palaeogeography and environmental change. Journal of Quaternary Science 18, 769-786.

Kasprzak, L., Lisicki, S., 1999. Szczegółowa mapa geologiczna Polski w skali 1:50 000 arkusz Kobułty (Detailed Geological Map of Poland, 1:50,000, sheet Kobułty). Państwowy Instytut Geologiczny.

Kenig, K., 1998. Petrogaficzne podstawy stratygrafii glin morenowych Polski północno-wschodniej (Petrographic foundations of till stratigraphy of northeastern Poland). Biuletyn Państwowego Instytutu Geologicznego 380, 1-99.

Kotański, Z., 1977. Rozwój paleotektoniczny wyniesionej części starej platformy w Polsce $\mathrm{w}$ wałdaju i w kambrze. (Palaeotectonic development of the uplifted part of the old East European platform in Poland, during the Valdaian and the Cambrian) Biuletyn Instytutu Geologicznego 303, 15 - 40.

Książkiewicz, M., Oberc, J., Pożarski, W., 1974. Mapa tektoniczna Polski (Tectonic Map of Poland), Wydawnictwa Geologiczne.

Lisicki, S., 2003. Litotypy i litostratygrafia glin lodowcowych plejstocenu dorzecza Wisły (Lithotypes and lithostratigraphy of tills of the Pleistocene in the Vistula drainage basin area, Poland). Prace Państwowego Instytutu Geologicznego 177, 1-105.

Mańkowska, A., Słowański, W., 1968. Mapa Geologiczna Polski 1:200 000, arkusz Olsztyn (Geological Map of Poland, 1:200,000, sheet Olsztyn), Polish Geological Institute. Warszawa.

Mańkowska, A., Słowański, W., 1980. Objaśnienia do Mapy Geologicznej Polski 1:200 000, arkusz Olsztyn (Explanations to Geological Map of Poland, 1:200,000, sheet Olsztyn) Polish Geological Institute, Warszawa.

Morawski, W., 1984. Osady wodnomorenowe (Watermorainic sediments). Prace Instytutu Geologicznego 58, 74 pp. Warszawa.

Morawski, W., 1985. Pleistocene glacigenic sediments of the watermorainic facies. Quaternary Studies in Poland 6, 99-116.

Morawski, W., 1989. Watermorainic sediments: Origin and classification. [In:] R.P. Goldthwait, C.L. Matsch (Eds): Genetic Classification of Glacigenic Deposits 143144. Balkema. Rotterdam/Brookfield.

Morawski, W., 2001. Szczegółowa mapa geologiczna Polski w skali 1:50 000 ark. Jeziorany (Detailed Geological Map of Poland, 1:50,000, sheet Jeziorany). Polish Geological Institute.

Morawski, W., 2003a. Objaśnienia do Szczegółowej mapy geologicznej Polski w skali 1:50 000 ark. Jeziorany (Explanations to Detailed Geological Map of Poland, 1:50,000, sheet Jeziorany). Polish Geological Institute.

Morawski, W., 2003c. Reconstruction of ice-sheet movement from the orientation of linear glacial landforms and glaciotectonic deformations near Kronowo (western Mazury, Poland). Geological Quarterly 47/4, 339-356.

Morawski, W., 2005a. Warmińska prowincja paleogeograficzna plejstocenu (południowo-wschodnia Polska) (The Warmia palaeogeographic province of the Pleistocene, north-eastern Poland). Przeglad Geologiczny 53, (6), 477-488.

Morawski,W.,2005b.Reconstructionoficesheetmovement from the orientation of glacial morpholineaments (crevasse landforms): an example from northeastern Poland. Geological Quarterly 49/4, 403-416.

Morawski, W., 2009a. Szczegółowa mapa geologiczna Polski w skali 1:50 000 ark. Biskupiec (Detailed Geological Map of Poland, 1:50,000, sheet Biskupiec). Polish Geological Institute.

Morawski, W., 2009b. Szczegółowa mapa geologiczna Polski w skali 1:50 000 ark. Dźwierzuty. (Detailed Geological Map of Poland, 1:50,000, sheet Dźwierzuty). Polish Geological Institute.

Morawski, W., 2009c. Objaśnienia do Szczegółowej mapy geologicznej Polski w skali 1:50 000 ark. Dźwierzuty (Explanations to Detailed Geological Map of Poland, 1:50,000, sheet Dźwierzuty). Polish Geological Institute.

Morawski, W., 2009d. Neotectonics induced by ice-sheet advances in NE Poland. Geologos, 15, 199-217 (this issue).

Morawski, W., 2009e. A reconstruction of the Vistula ice stream during the last glaciation. Geological Quarterly 53/3,

Punkari, M., 1997. Glacial and glaciofluvial deposits in the interlobate areas of the Scandinavian Ice Sheet. Quaternary Science Revievs 16, 741-753.

Roman, M., 2008). Rekonstrukcja kierunku ruchu lądolodu lobu Wisły w obszarze Pojezierza Kujawskiego i Kotliny Płockiej (Reconstruction of ice flow directions of the Vistula ice sheet lobe in the Kujawy Lakeland and the Płock Basin area). Acta Geographica Lodziensia $93,67-85$.

Słodkowska, B., 2009. Palynology of the Palaeogene and Neogene from the Warmia and Mazury areas (NE Poland). Geologos, 15, 219-234 (this issue).

Stokes, C.R, Clark, C.D., 2001. Palaeo-ice streams, Quaternary Science Reviews 20, 1437-1457.

Tyski, S., 1974. Obszar wyniesiony platformy wschodnio europejskiej. [In:] W. Pożaryski (Ed.) Budowa geologiczna Polski. Tektonika, 1. Niż Polski. Wydawnictwa Geologiczne, Warszawa.

Wysota, W., Molewski, P., Sokołowski, R.J., 2009. Record of the Vistula ice lobe advances in the Late Weichselian glacial sequence in north-central Poland. Quaternary International 30, 1-16.

Manuscript received 15 September 2008; revision accepted 21 October 2009. 